\title{
ARSITEKTUR RUMAH ADAT LAKI-LAKI JAME OWAA SUKU MEE
}

\author{
(The Architecture of Mee Traditional House)
}

\section{Martinus Tekege}

Balai Arkeologi Papua

Jl. Isele Waena Kampung, Heram, Kota jayapura, Provinsi Papua

Pos-el : martinustekege77@gmail.com

\begin{tabular}{|c|c|}
\hline INFO ARTIKEL & $A B S T R A C T$ \\
\hline $\begin{array}{l}\text { Histori Artikel } \\
\text { Diterima : } 3 \text { Mei } 2021 \\
\text { Direvisi : } 10 \text { Mei } 2021 \\
\text { Disetujui : } 1 \text { Juni } 2021 \\
\end{array}$ & $\begin{array}{l}\text { The tradisional house on a particular group of people is a } \\
\text { reftection of local knowledge inherited from generation to } \\
\text { generation. This paper examines about the tradisional house of }\end{array}$ \\
\hline $\begin{array}{l}\text { Keywords: } \\
\text { The architecture house is } \\
\text { a tradisional man (jame } \\
\text { owaa) tribe Mee }\end{array}$ & $\begin{array}{l}\text { a tradisional house Mee culture modals people not of legacy } \\
\text { and the water lake eraporate. The results of surveys and } \\
\text { interview. Knowing the concept and philosophy and conltural } \\
\text { values of Mee tradisional house. The etnoarchaeology approach }\end{array}$ \\
\hline $\begin{array}{l}\text { Kata kunci: } \\
\text { Arsitektur, rumah }\end{array}$ & $\begin{array}{l}\text { used to reconstruct the meaning of the culture in the past. The } \\
\text { purpose of this research is to khow the development of shape, }\end{array}$ \\
\hline tradisional, suku mee & $\begin{array}{l}\text { type tunctio and make material area in Tigi lake. In the } \\
\text { Neolithic period, Mee tribe living area Danau Tigi, human } \\
\text { primordial house simple. The resident brim lake, shore, valley, } \\
\text { mountain, and river. }\end{array}$ \\
\hline
\end{tabular}

\begin{abstract}
ABSTRAK
Rumah tradisional pada kelompok masyarakat tertentu merupakan refleksi dari kearifan lokal yang diwariskan secara turun temurun. Tulisan ini mengkaji rumah tradisional suku bangsa Mee. Salah satu masalah yang belum perna dijawab adalah rumah tradisional suku Mee nilai-nilai budaya manusia sudah mulai lemah dari warisan dan penguapan air Danau penduduk menyalami. (Ditambah bentuk rumah tradisional suku Mee konsep dan filosofinya, serta nilai budaya. Dalam penelitian ini digunakan metode survei dan wawancara. Dalam pendekatan etnoarkeologi diharapkan budaya masa lampau dapat direkontruksi lewat data etnografi dari tradisi masyarakat yang masih hidup, Tujuan penelitian adalah untuk mengetahui perkembangan bentuk, jenis, fungsi dan bahan perbuatannya di kawasan Danau Tigi. Pada masa Neolitik manusia Mee hidup kawasan Danau Tigi, manusia purba keluar dari gua-gua membuat rumah sederhana, Ditempattempat tepi danau, pantai, lembah, gunung dan sungai.
\end{abstract}




\section{PENDAHULUAN}

Penghuni penduduk pesisir hingga pedalaman,Papua memiliki potensi rumah tradisional yang menarik untuk dikaji dari berbagai aspek arsitekturnya. Untuk itu, kajian lebih lanjut menyenai rumah tradisional etnis Papua ini, diarakan untuk memperlihatkan bahwa arsitektur rumah yang didirikan akan senantiasa mengambarkan karakteristik kebudayaan masyarakat pendukungnya, (Mahmud, 2010).

Papua memiliki tujuh wilayah adat, rumah adat tradional bentuk jenis masingmasing yaitu Mamta, Saireri, Bomberai, Domberai, Ha-Anim, La-Pago, dan wilayah adat Mee-Pago. Pedalaman dataran tinggi Papua, ada tiga wilayah adat, bentuk dan jenis rumah adat masing-masing, di daerah adat istiadat yang populer yakni wilayah adat Annim, wilayah adat La-pago, dan wilayah adat Mee-pago, suku yang terkenal delapan suku bangsa, dan yang kecil dua puluh suku bangsa, Bahasa-bahasa ibu yang di temukan kawasan pedalaman di sana, beberapa kelompok dalam satu kelompok bahasa ibu, bisa saja menggunakan bahasa yang tidak saling mengerti satu sama lain, tetapi garis dasar, perbendaharaan kata dan tata bahasanya adalah sama. Penduduk dataran tinggi Papua ada tiga suku etnik yaitu wilayah adat Annim, wilayah adat Lapago dan wilayah adat Mee-pago, suku yang populer, jadi suku yang terkenal wilayah pegunungan tengah atau dataran tinggi, ada delapan suku etnik atau kelompok besar sebagai berikut; Suku Mee, Suku Moni, Suku Damal atau Amungme, Suku Lani, Suku Yali, Suku Mek atau Ketimbang dan Suku Ok/Muju (Papuaweb.org).

Ukuran rumah sama laki-laki suku Mee berbeda dengan rumah perempuan suku Mee. Tetapi kita penelitian dilanjutkan perbandingan beda jauh, dilihat bentuk denah ukuran segi empat, rumah laki-laki ukuran rumah adat, 3,5 X 3,5 sedangkan rumah adat perempuan dengan ukuran rumah 2,5 X 2,5. Semua sama bentuk badan ciri-ciri, material bahan yang digunakan sama pria maupun wanita. Jadi suku Mee ada dua rumah adat turun-temurun yakni rumah adat kuno pria, dan rumah adat kuno wanita. Tetapi ukuran gambar denah beda jauh rumah adat mereka. Menurut beberapa informan suku Mee sendiri menyatakan. Ketika membangun rumah tergantung dari ukuran rumah besar sedang dan kecil, dari pemilik rumah huniannya. Rumah adat perempuan suku Mee di samping kiri atau kanan dan di belakang rumah laki-laki sekitar jarak lima, enam meter atau satu atap dengan rumah induk laki-laki. Aktivitas 
mereka jalan sendiri sendiri di dalam rumah, sekitar pekarangan di luar rumah kerja (Pekey, 2008).

Suku Mee bermukim di Danau Paniai, Danau Tege, dan Danau Tigi (Howay dan Yaam, 1994:246). Menurut Kal Muller (2008:195) suku Mee adalah penduduk dataran tinggi pertama yang mengadakan kontak jangka panjang dengan bangsa Eropa, dan juga menjadi yang pertama menerima pos pemerintahan serta misionaris.

\section{Nitihaminoto}

(2008:83)

menjelaskan bahwa masyarakat yang bermukim di danau disebut dengan komunitas danau, dalam aktivitas kesehariannya selain mata pencaharian juga religi, kesenian, organisasi sosial dan aspek budaya lainnya. Aktivitas-aktivitas itu dilakukan berdasarkan tingkah laku dari pendahulunya.

Lingkungan tempat tinggal orang Mee yang bergunung-gunung tinggi dengan lembah-lembah yang dalam, hutan-hutan tropis dan padang-padang rumput dengan iklim sedang, menyebabkan sistem mata pencaharian hidup orang Mee terdiri dari pertanian lading dan diolah secara intensif adalah ubi jalar. Di samping berladang dan beternak babi, jenis-jenis mata pencaharian hidup tambahan lain juga dilakukan, misalnya berburu (babi hutan, biawak, katak, kuskus, dan burung) dan meramu berbagai jenis buah-buahan hutan yang dapat dimakan, misalnya buah merah (Mansoben, 1995:109).

Pada umumnya batas wilayah Suku Mee yaitu Kampung Kegegata sampai Kampung Makitaka,. Jumlah klan SUuku Mee yaitu 150 marga yang tersebar di tiga kabupaten yaitu: Kabupaten Paniai, Kabupaten Deiyai dan Kabupaten Dogiyai. Jika menggunakan bahasa ibu kawasan wilayah adat penghuni tiga Kabupaten ini yaitu Mee, kemudian dialek bahasa beda sedikit tetapi, ujung kata bisa dengar perbendaraharaan kata ini. Penghuni margamarga hidup tiga kabupaten suku Mee ini (Tekege, 2009).

Rumah suku Mee diibedakan atas empat, ciri - ciri bentuk dan fungsi, rumah adat masa kini yaitu, 1. Rumah adat laki laki, Jamee Owaa, 2. Rumah adat berdansa Yuwo owaa. 3. Rumah adat perempuan kewita Owaa. 4. Rumah adat keluarga Uguwo Owaa. Ke empat rumah adat ini memiliki kriteria sendiri - sendiri yang dibedakan satu dengan lainnya. Secara filosofis pada suku bangsa Mee, yang mendalam ke dalamnya, dimuat pembahasan selanjutnya, analisis struktur aspek dan nilai bangunan rumah adat suku Mee. 
Khusus untuk rumah adat tradisional laki - laki jame owaa umumnya ditempati empat sampai lima kepala keluarga. Istri istri dan anak - anak tinggal di rumah sendiri di samping kiri, kanan dan di belakang, jame owaa membuat rumah perempuan kewita atau gebou. Kepala keluarga yang di tinggal laki - laki jame owaa itu tinggal duduk, tidur dan menyimpan anak panah dan segala atribut tidak sembarang tempat taruh, atau menyembunyikan rahasia di atas loteng rumah adatnya. Dan harus sesuai dengan tempat tidurnya masing-masing menyimpan. Rumah jame owaa fungsinya untuk tempat bermusyawarah, berdiskusi, tempat menimpan segala atribut, dan tempat memecakan segala masalah yang terjadi suku bangsa Mee, maupun suku lain.

\section{METODE PENELITIAN}

Metode penelitian merupakan, cara yang ditempuh sehubungan dengan upayah ilmiah untuk memahani suatu objek penelitian. Penelitian ini bercorak Deskriptif kualitatif. Pemilihan metode ini dimaksud untuk memahami dan menggambarkan protes pengambilan pengolahan dan mendeskripsi data penelitian.

Teknik yang digunakan dalam mengumpulkan data dilapangan adalah teknik observasi, wawancara, studi pustaka dan daftar informan. Ketiga teknik tersebut sebagai berikut: 1 observasi, dalam teknik ini dilakukan dengan mengamati dan mendeskripsikan hal-hal yang berkaitan dengan Arsitektur rumah adat tradisional totaa owaa, pemgambilan foto dan pengambilan dilakukan saat Observasi. Pengamatan terhadap rumah adat suku Mee dilakukan pada, teknik pembuatan, bahan yang dibuat, bentuk denah ukuran rumah, teknik ikat tali. 2 Wawancara yang dilakukan terhadap beberapa informan seperti kepala suku, kepala adat, tua-tua adat pria, dan tua-tua adat wanita suku Mee, dan budayawan budayawati suku Mee. 3 Pengumpulan data dilakukan dengan mengumpulkan beberapa studi literatur, berupa skripsi dan buku-buku yang terkait dengan arsitektur rumah tradisional suku bangsa. 4 Informan dalam penelitian ini dipilih secara langsung yang terdiri dari para orang tua bapak, ibu serta pemuda, perangkat adat yang terdiri dari kawasan Danau Tigi, serta kepala suku, kepala desa, tokoh budayawan dan tukang-tukang bangunan. Selain itu peneliti juga menggunakan informan tambahan yang terdiri dari guru dan mantri. Yang tepat berada di depan pintu gerbang wilayah adat Distrik Tigi Barat. 


\section{HASIL DAN PEMBAHASAN}

Rumah tradisional suku Mee, diikuti jejak hunian kuno dari leluhur, bangunan rumah adat kuno. Rumat adat dapat bertahan sampai ke generasi kelima belas sampai masa kini, ada seluruh Kabupaten Deiyai, penduduk memiliki hunian masa kini. Bergerak dari misih melalui gereja-gereja Katolik sudah membangun, dan juga masyarakat masih bertahan rumah adat sendiri, beberapa respondens suku Mee. Ada lima Distrik membuat rumah adat tradisional mempertahankan turun-temurun mereka, penduduk yang membuat rumah, bermukim dataran rendah, di pingir danau, dipinggir sungai, dataran tinggi dan kaki gunung.

Secara umum setiap etnik memiliki beberapa jenis bangunan tradisional, bentuk dan tipologi seperti rumah tempat tinggal, rumah ibadah, rumah tempat musyawarah, rumah tempat berdangsa, rumah tempat istirahat di ladang, dan rumah tempat piarahan ternak jinak, penduduk dapat piarahan secara induvidu. Secara filosofis pada suku bangsa Mee, secara mendalam kedalam beberapa bagian rumah adat masa kini yaitu:

a. Rumah adat laki-laki jaamee owaa;

b. Rumah adat berdansa juwoo owaa; c. Rumah adat perempuan jaagamoo owaa dan;

d. Rumah adat keluarga uguwoo owaa;

\section{Rumah Adat Laki - Laki Jamee Owaa}

Demikian halnya di daerah Mee, bangunan tradisional yang bertahan hingga sekarang ini adalah rumah tempat tinggal jame owaa. Sedangkan rumah adat perempuan, rumah adat keluarga dan perumahan penduduk semuanya bentuk jenis modern, sudah mengalami perubahan, bentuk menjadi bangunan permanen sehingga ciri khas arsitektur tradisional suku Mee tidak nampak lagi, rumah tempat musyawarah hanya memanfaatkan bangunan rumah atau tempat balai kampung / Desa, begitu pula rumah tempat dansa sebagai harus musyawarah bersama kemudian dibangun klan - klan yang terdekat, atau rukun bersama suku Mee. Pada hal rumah adat suku Mee, menurut responden dengan tua-tua budayawan dan budayawati rumah adat suku Mee, ada dua macam rumah adat kuno masih bertahan yaitu rumah adat wanita dan rumah adat pria dari pewarisan suku Mee.

Rumah adat laki-laki jame owaa ialah rumah adat, yang tempat tinggal khusus untuk pria, dan anak yang mau memasuki atau mendaki kedewasaan, Jame 
owaa berarti rumah yang tempat belajar, mendidik anak, mencari tauh, mendalami, menimba, mengerti, memahami dan menguasai 'dimi' sebagai akar budii, pemikiran, pengetahuan, pengajaran, pendidikan pandangan dan segala hal yang berkaitan dengan, kebudayaan touye mana suku Mee yang miliki, dengan ini setiap hari para orang tua menasehati anak-anaknya dengan perkataan dimi motii, dimi gaida (terimalah dan kuasailah akal budi pikiran), dan pengetahuan. Rumat adat laki-laki ini, mendidik masa kini dan masa yang akan datang motivasi masa usia dini, yang mulai mendaki kedewasaan. Khusus untuk rumah adat tradisional laki - laki jame owaa umumnya ditempati empat sampai lima kepala keluarga. Istri - istri dan anak - anak tinggal di rumah sendiri di samping kiri, kanan dan di belakang, jeme owaa. Membuat rumah perempuan kewita atau gebou. Kepala keluarga yang di tinggal laki - laki jame owaa itu tinggal, duduk, tidur dan menyimpan anak panah dan segala atribut tidak sembarang tempat taruh, atau menyembunyikan rahasia di atas loteng rumah adatnya (kidouda). Dan harus sesuai dengan tempat tidurnya masing - masing menyimpan. jeme owaa Sebagai simbol mengandung laki-laki bertanggung jawab atau biyaksana, dalam rumah adat laki-laki jame owaa .

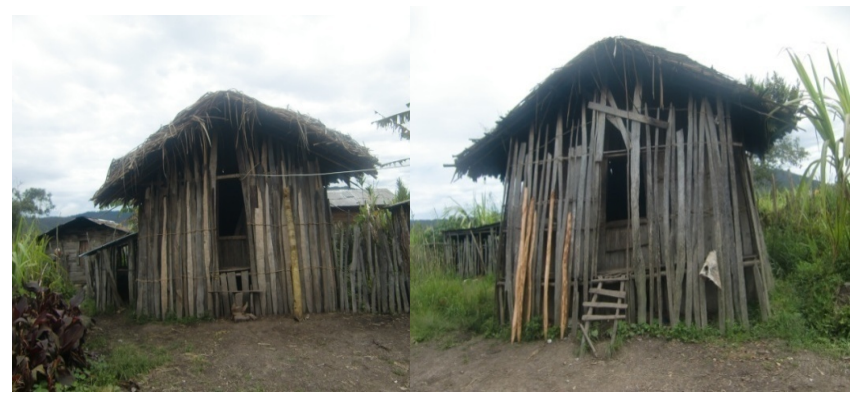

Gambar 1. Kondisi Salah Satu i Rumah Adat Pria Suku Mee (dokumentasi: Tekege)

Rumah adat laki-laki jame owaa, rumah adat, fungsinya untuk, tempat bermusyawarah, berdiskusi, tempat menimpan segala atribut, dan tempat memecakan segala masalah yang terjadi suku Mee, maupun suku lain. Membimbing, membina dan mengajar mendidik itu oleh orang-orang yang tertua, orang-orang yang pengalaman, atau orang yang berpengaruh kuat sesuai bakat dan talentanya. Orangtua yang memberikan membimbin, membina, mendidik kepada kaum muda atau anakanak laki-laki maupun anak perempuan atau juga kepada kaum ibu-ibu atau bapak-bapak didalam rumah adat sesuai dengan bakat, minat talentanya masing-masing itu, agar tidak melangar atau menjaga dan melaksanakan kemurniaan, kekudusan dan kesucian dalam berbangai bidang.

Orang-orang tua yang mengajar 
kepada anak muda mau menuju dewasa ini, bagian bidang-bidang yang lain itu mereka sampaikan secara garis besar atau gambaran umum saja, tetapi sesuai talenta atau bakat akii ide-ide yang ia miliki, seperti orang yang selalu perperan dalam beraktivitas oda owaa daa, baik cara menanamnya, memeliharanya. Menyelesaikan masalah segala masalah. Demikian pula orang yang tahu bakatnya memelihara ternak babi dan lain-lainnya juga seperti itu. Dan untuk memberikan pemahaman dan pengajaran itu, tepat waktunya.

Pada saat hidup orangtua dan leluhur nenek moyang suku Mee tidak bicara dan cerita banyak, mereka sibuk pada aktivitas, karena kalau mereka tidak kerja, pada sore harinya mereka merasakan kehausan, kedinginan, dan kelaparan mereka merasa itu tetapi juga pada waktu ibu melahirkan (jokapai) atau pada pesta babi (juwo) maka sepanjang hari pada setiap hari kerja keras. Jameowa itu selalu duduk bersama khusus untuk pria, tidur, menyimpan anak panah dan segala atribut sesuai dengan tempat tidur yang mereka sudah dibuat atau ditempatkan di loteng masing-masing. Jame owa juga berfungsi untuk tempat bermusyawarah, diskusi, sengalah masalah yang terjadi di dalam kampung maupun di luar kampung (suku-suku lainnya), segala persoalan diselesaikan di dalam rumah jame owaa sebangai tempat latihan bagi para pemudapemuda menuju kedewasaan. Tempat upacara religius, kemudian upacara-upacara adat, sebangai tempat untuk rumah inisiasi, dan sebagai menyimpanan atribut-atribut lain sebagainya. Segala persoalan besar dan persoalan kecil harus selesaikan didalam rumah adat mereka. Kemudian rumah adat yang diwariskan oleh nenek moyang ada dua macam rumah kuno yaitu Rumah adat pria dan rumah adat wanita suku Mee.

Kini suku Mee yang hidup di kota tidak mempunyai jamee owaa, mereka tinggal bersama hidup dengan keluarga karena budaya modern masuk di kawasan wilayah Paniai, tidak memiliki rumah adat lagi. Observasi rumah responden Kampung Geigeikebo semua bergabung tinggal bersama keluarga inti, dari responden masih bertahan rumah adat laki-laki ada dua bentuk asli rumah adat, kemudian yang satu itu badan rumahnya asli tapi atap sudah diganti dengan seng, ikut pengaruh zaman modern, (survei lapangan situs", situs Kampung Geigeikebo ada tiga bentuk rumah adat dari responden). kemudian responden penghuni rumah tinggal bersama dengan anak-anak, dan suami istri, segala hukum adat budaya melemah, wawasan dan kemampuan berpikir secara orang dewasa 
sudah tidak ada lagi, karena semuanya bersumber dari jawee owaa, pemikiran lakilaki tidak ada lagi, apa bila seorang diri laki - laki tinggal dengan anak-anak dan perempuan pemikiran sebangai laki-laki otomatis sendirinya hilang. ikut terlibat turun menjadi pemikiran perempuan atau anak-anak. Itu kenyataan masa kini.

Istri dan anak-anak dilarang masuk di rumah jame owa karena anak tidak bisa berkembang cepat fisik maupun mental. Untuk pertumbuhan fisik maupun mental leluhur suku Mee sudah tau bahwa anak laki-laki menuju ke dewasa jika pertumbuhan rambut sekitar alat kelamin dibawah, atau ketiak dan kumis situlah dia anak laki-laki sudah mulai tumbuh, kemudian bebas masuk dirumah jame owaa rumah adat pria. Istri-istri dan anak-anak dilarang masuk di rumah jawee owa, karena hukum-hukum adat ketentuan dari warisan nenek moyang. Hukum adat dalam rumah jame owa a artinya segala usaha dalam sosial ekonomi maupun mawas diri laki-laki dalam berbagai aktivitas sehari-hari terganggu dalam kesehatan.

Penata tempat tinggal rumah jemeowaa mengatur dengan benar. Salah satu jame owaa termuat dari tiga - lima lebih kepala keluarga termuat (di rumah orang kaya) tonowi bisa gabung dengan mereka.
Anak-anak dan ibu - ibu di rumah kewita gebou sendiri bagian kiri, kanan, depan dan belakan, tapi rumah ukurannya sama $3,5 \mathrm{X}$ $3,5 \mathrm{~m}$.

Jan Boelaars (1986) yang melakukan penelitian tentang rumah adat suku Mee, menurutnya ukuran rumah suku Mee baik laki-laki dan perempuan yaitu rumah lakilaki, ukuran rumah 3,5 X 3,5 m, sedangkan rumah perempuan ukuran 2,5 X 2,5 m. Menurut suku bangsa Mee sendiri, ketika membangun rumah tergantung dari ukuran rumah besar, sedang dan kecil dari pemilik rumah penghuninya. Menurut suku Mee, biasanya rumah perempuan itu di sebelah kiri atau kanan dan dibelakang rumah, satu atap dengan rumah laki - laki. Aktivitas mereka jalan sendiri sendiri didalam rumah maupun di luar rumah.

Rumah tradisional suku Mee pada umumnya rumah panggung atau berkolong di daerah pedalaman Paniai, Deiyai dan Dogiyai, merupakan salah satu bentuk adaptasi atas lingkungan yang merupakan daerah pasang surut air danau, dan sungai. Dengan rumah panggung berbagai permasalahan tersebut akan teratasi penduduk. Sedangkan rumah panggung yang berada di pedalaman Papua, kawasan wilayah adat Paniai, dimana rumah panggung berfungsi sebagai tempat 
berlindung, selain juga meminimalisasi berbagai ganguan binatang buas. Di sisi lain pendirian bangunan panggung seperti gubuk di ladang juga dapat dikatakan sebagai strategi adaptasi dalam upaya memenuhi kebutuhan pangan.

Perubahan-perubahan adat dan kebiasaan di Papua berlangsung sangat cepat (Koentjaraningrat dan Ajamiseba, 1994: 433). Dalam beberapa hal tingkah laku manusia secara genetis telah diprogram, artinya perbedaan cara hidup. dan wilayah budaya suatu masyarakat dapat mengasilkan suatu dasar budaya yang sama yaitu rumah panggung. Bagaimana masyarakat yang berada di pedalaman memiliki strategi yang sama dalam mengadapi permasalahan berbeda yaitu permasalahan pasang surut air dan juga permasalahan binatang buas.

Dalam mengadapi lingkungan baik itu kondisi pasang surut air atau pun juga binatang buas maka konsep yang telah terprogram dari genetis manusia itu adalah membuat rumah pangung. Tentunya faktor genetis ini terjadi karena sebelumnya kelompok manusia itu pendahulunya telah melakukan hal yang sama sehingga strategi adaptasi yang dilakukan nenek moyangnya membentuk sikap yang sama dalam upaya mengadapi lingkungan tempat tinggalnya.

Lokasi yang dipilih oleh suku Mee untuk mendirikan rumahnya adalah mengikuti garis tanah adat tersendiri sendiri untuk dibangun dan terpencar dengan pola keletakan di darat, dekat danau dan sungai. Ketiga lokasi pengolompokan hunian tersebut masih berada masih berada di wilayah pegunungan tengah sehingga masih sangat dipengaruhi oleh pasang surut air danau dan sungai khusus untuk rumah berdiri di atas perairan air danau, sungai dan perairan lainnya.

Keadaan air danau, air sungai pada musim hujan meluap dan mengenai daerah pertaniaan sekitarnya, peluapan ini disebabkan karena banyak Sungai besar maupun kecil bermuara menuju ke danau dan tanah yang kurang baik sehingga penyerapan air hujan ke dalam tanah sangat lambat. Keadaan kondisi Danau Tigi tersebut.

Akibat penguapan air danau serta air sungai mengakibatkan rumah tradisional cepat rusak, untuk itu pemerintah setempat harus sediakan ladang baru, membuat pemukiman untuk hunian masyarakat tinggal tidur mereka.

Rumah induk tota owaa terdiri dari ruang tamu, ruang tidur, ruang dapur, sekalian dengan satu rangkaiannya rumah, satu jalusi, atau satu atap rumah. Ruang teras bagian depan, kamar mandi tidak ada 
pergi dekat sungai, Danau dan sumur, sedangkan wc/kakus ditempatkan di belakang rumah, di samping rumah kediaman mereka, masyarakat membuat sumur, untuk buang air besar dan kecil samping rumah. Bentuk asli rumah, kemudian "rumah pria" yame owaa sebagai tempat tidur suku bangsa Mee, dan kolom rumah, samping rumah dan belakan rumah biasanya dijadikan tempat untuk ternak pemeliharaan babi, kelinci, kambing dan sebagainya. Sedangkan Loteng rumah tempat menyimpan kayu bakar, anak panah dan atribut alat mata pencaharian lainnya. Dapat dalam tulisan ini difokuskan pada bangunan rumah adat laki-laki jame owaa, tempat tinggal karena masih banyak yang mempertahankan ciri khas arsitektur rumah adat tradisional suku Mee.

Tipologi rumah adat orang Mee berbentuk panggung yang terdiri atas tiga susun. Susunan pertama disebut kiidouda yang letaknya paling atas, meliputi atap dan loteng. Susunan kedua disebut Mee umida (ruang/kamar tengah) yaitu ruang yang ditempati hunian rumah kamar tidur, bagian tengah, dengan sekalian tungku api, dan susunan ketiga disebut ema mijo (kolong rumah) yang letaknya paling bawah. Demikian pula bentuk rumahnya segi empat, terdiri atas dagu wiya (dua bagian). Bagian pertama disebut (akaagau) petak depan, kemudian kedua disebut mee umii dangu/wouto ka dagu tempat tidur hunian penduduk (petak belakang). Gambaran tiga susun dan dua petak menujukan makna pada filosofi suku Mee yang berbunyi; widaagoma ka potoo teeawii enapa awii, wiyago kaaki umina gaipeu (tiga tak terpisahkan, dua saling membutukan). Adapun tak terpisahkan itu adalah aspek hukum dan demograsi, sedangkan tiga saling membutukan adalah aspek ekonomi, keadilan, dan persatuan. Dalam pengertian ini, suku Mee. Serta sangat menjujung tinggih nilai keadilan dan persatuan dalam kehidupan masyarakat terutama dibidang ekonomi.

Adapun tak terpisahkan itu adalah aspek hukun dan demograsi, sedangkan tiga saling membutukan adalah aspek ekonomi, keadilan, dan persatuan.

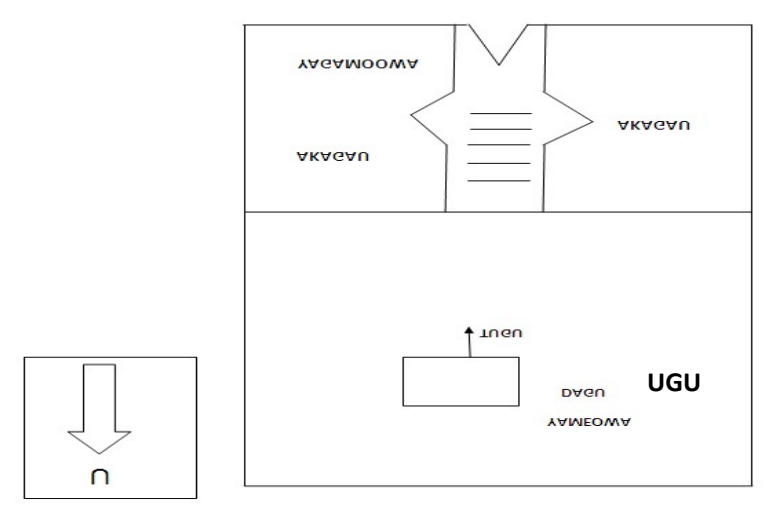

Gambar 2. Denah Rumah tradisional suku 
Mee (Sumber: Tekege)

Keterangan:

Yame owaa / emah owah: Ruang laki laki.

Akagau = yagamo owaa : Serambih -

Ruang Perempuan

Ugu : Tungku api

Fungsi dan bahan-bahan bangungan rumah adat Mee, yang dimaksudkan dengan rumah disini ialah "rumah adat" yang masih terdapat dikepulauan Papua fungsi asli dari pada rumah ini telah lenyap, bentuk yang terdapat pada rumah-rumah sangat berlainan bagi setiap suku bangsa Melanesia.

Fungsi dan bahan yang dipergunakan membangun rumah-rumah ini pada umumnya wilaya meewoodide suku Mee sama sebagai berikut yaitu:

1. Atap bouyo dibuat dari daun rumbia, daun alang - alang, daun pandang jaagee, dan dauti bubugi "nama pohon" "piyaa kado" kulit kayu. Berfungsi untuk membuat atap rumah adat suku Mee.

2. Dinding jagaa dari papan kayu yang sudah runcing dan dibuat manual, dari kapak besi atau parang, zaman dulu tidak mengenal kapak perunggu, besi, parang, menggunakan kapak batu, mauumi masa paleolitik pada masa itu tingkat tradisi kebudayaan atas dasar teknik pembuatan alat batu dari masa berburu dan mengumpulkan makanan sederhana, sedangkan tingkat kebudayaan pada masa prasejarah ciri-ciri berupa unsur kebudayaan seperti peralatan yang terbuat dari batu yang telah diasah yang disebut pada masa Neolitik (Soejono, 1994). Banyak macam aktivitasaktivitas mereka menggunakan alat-alat batu, batu Maumi yaitu Maumi belah kayu, maumi potong kayu, maumian buat berkebun, mauumi, membuat pagar, dan "mauumi " dan alat-alat serpih potong sayur-sayuran, potong kuku, dan kena anak panah pada saat medang perang, (kapak batu). Mauumi ialah alat kapak batu yang digunakan aktivitas sehari-hari, masyarakat lokal.

3. Lantai kejage dari kayu buah, belahan - belahan batan pohon, dan kulit nibun. Papan kayu dan kulit nibun fungsinya untuk membuat lantai rumah, pintu dan loteng rumah, loteng fungsi untuk tempat menimpang segalah atribut, aktivitas dilaksanakan dalam setiap 
bagian di dalam rumah adat tradisional, contohnya gelang tradisional, korek api tradisional, anak panah, alat membuat noken (merajut), dan sebagainya.

4. Tali temati uutih, dan ada yang dibilang budah, dan uutih kata lain nama marga / klan suku mee. Dengan ini fungsi tali rotan tersebut dibelah-belah lalu gabahnya kasih ke luarkan kemudian di jemur, setelah itu sudah di kering tali rotan dapat menggunakan anyaman kayu atau papan dinding mengikat satu sama lainnya. Pengikat kontruksi berupa tali rotan atau jenis tumbuhan lain, tidak ada struktur yang terkait secara kuat, semuanya tergantung pada kekuatan tali pengikat.

5. Tiang kemoomaa dinding dan kerangka rumah. Tiang yang menggunakan kayu lokal, atau bahan-bahan yang menggunakan tersebut; bidaa piya (kayu besi) digii, motai, amoo nama kayu, dan sebagainya, fungsi untuk kayu ini biasa menggunakan kayu tiang rumah.

6. Tungku api $u g u$ dibuat dari tanah lihat, campur batu tebal halus dan panjang, Papan dan tiang kayu di panggung dalam rumah adat suku Mee. Tungku api fungsinya untuk menjemur badan pada malam hari atau pagi subuh, karena hembusan angin masuk melalui celah-celah tiang atau papan kayu. Dan fungsi lainnya untuk masak memasak dan lainnya.

\section{PENUTUP}

Rumah adat tradional jame owa adalah untuk tempat bermusyawarah, diskusi, sengalah masalah yang terjadi di dalam kampung maupun di luar kampung (sukusuku lainnya), segala persoalan diselesaikan didalam rumah adat jame owaa sebagai tempat latihan bagi para pemuda-pemuda menuju kedewasaan. Tempat upacara religius, kemudian upacara-upacara adat, sebagai tempat untuk rumah inisiasi, dan sebagai menyimpanan atribut-atribut lain sebagainya. Segala persoalan besar dan persoalan kecil harus selesaikan didalam rumah adat mereka. Kemudian rumah adat yang diwariskan oleh nenek moyang ada dua macam rumah kuno yaitu Rumah adat pria dan rumah adat wanita suku Mee.

Kini tidak mempunyai jamee owaa sekarang tingal bersama hidup dengan keluarga karena budaya modern masuk 
dikawasan wilayah Paniai, tidak memiliki rumah adat lagi. Observasi rumah tradisionl di Kampung Geigeikebo, penghuninya bergabung tinggal bersama keluarga inti, dari responden masih bertahan rumah adat laki-laki ada dua bentuk asli rumah adat, kemudian yang satu itu bentuk rumahnya asli tapi atap sudah diganti dengan seng, ikut pengaruh zaman modern, di Kampung Geigeikebo ada tiga bentuk rumah adat. Penghuni rumah tinggal bersama dengan anak-anak, dan suami istri, segalah hukum adat budaya melemah, wawasan dan kemampuan berpikir secara orang dewasa sudah tidak ada lagi, karena semuanya bersumber dari jawee owaa, pemikiran lakilaki tidak ada lagi, apabila seorang diri laki laki tinggal dengan anak-anak dan perempuan pemikiran sebangai laki-laki otomatis sendirinya hilang. ikut terlibat turun menjadi pemikiran perempuan atau anak-anak. Itu kenyataan masa kini.

Dalam mengadapi lingkungan baik itu kondisi pasang surut air ataupun juga binatang buas maka konsep yang telah terprogram dari genetis manusia itu adalah membuat rumah pangung/berkolong. Tentunya faktor genetis ini terjadi karena sebelumnya kelompok manusia itu pendahulunya telah melakukan hal yang sama sehingga strategi adaptasi yang dilakukan nenek moyangnya membentuk sikap yang sama dalam upaya mengadapi lingkungan tempat tinggalnya.

Akibat penguapan air danau serta air sungai, terjadi rumah-rumah yang ada di banggir Danau, dipingir kali, rusak, terhanus, lapuk, tali pengikat kayu longgar / terlepas, atap rumah daun rumbia, daun nibon, dan rumput-rumputan rusak, pagar rumah rusak dan lain-lain. Pemerintah setempat harus sediakan ladang baru, membuat pemukiman untuk hunian masyarakat tinggal tidur mereka.

Tipologi rumah adat orang Mee berbentuk panggung yang terdiri atas tiga susun. Susunan pertama disebut kiidouda yang letaknya paling atas, meliputi atap dan loteng. Susunan kedua disebut Mee umida (ruang/kamar tengah) yaitu ruang yang ditempati hunian penduduk rumah kamar tidur, bagian tengah, dengan sekalian tungku api, dan susunan ketiga disebut ema mijo (kolong rumah bawah) yang letaknya paling bawah. Demikian pula bentuk rumahnya segi empat, terdiri atas dagu wiya (dua bagian). Bagian pertama disebut (akaagau) petak depan, kemudian kedua disebut mee umii dangu/wouto ka dagu atau tempat tidur hunian penduduk (petak belakang). Gambaran tiga susun dan dua petak menujukan makna pada filosofi suku bangsa 
Mee yang berbunyi; widaagoma ka potoo teeawii enapa awii, wiyago kaaki umina gaipeu (tiga tak terpisahkan, dua saling membutuhkan). Adapun tak terpisahkan itu adalah aspek hukun dan demografi, sedangkan tiga saling membutuhkan adalah aspek ekonomi, keadilan, dan persatuan. Dalam pengertian ini, suku bangsa Mee. Serta sangat menjunjung tinggi nilai keadilan dan persatuan dalam kehidupan masyarakat terutama dibidang ekonomi.

\section{DAFTAR PUSTAKA}

Boelaars, Jan. 1986. Manusia Irian. Dahulu, Sekarang, Masa Depan. Jakarta: Gramedia. Howay, O., Paul Yaam. 1994. Masyarakat Mek di Sekitar Danau Paniai dalam Irian Jaya Membangun Masyarakat Majemuk (Koentjaraningrat (ed.). Jakarta: Djambatan.

http://www.papuaweb.org. diakses 13 November 2010.

Koentjaraningrat, D. Ajamiseba. 1994. Reaksi Penduduk Asli Terhadap Pembangunan dan Perubahan dalam Irian Jaya Membangun Masyarakat Majemuk (Koentjaraningrat (ed.). Jakarta: Djambatan.

Mahmud, Irfan. 2010. Arsitektur Rumah Tradisional Sentani Papua. Kementerian Kebudayaan dan Pariwisata.

Mansoben, J. R. 1994. Kebinekaan Sistem Kepemimpinan Tradisional di Irian Jaya dalam Irian Jaya Membangun Masyarakat Majemuk (Koentjaraningrat (ed.). Jakarta: Djambatan.

Muller, Kal. 2008. Mengenal Papua. Daisy Books.

Nitihaminoto, Gunadi. 2008. "Studi Permukiman Danau Pengembangan dan Pemberdayaannya di Indonesia" dalam Kumpulan Makalah Pertemuan Ilmiah Arkeologi IX. Jakarta: IAAI. Hlm. 78-88.

Pekey, Titus. 2008. Manusia Mee di Papua Proteksi Kondisi Masa Dahulu, Sekarang dan Masa Depan di atas Pedoman Hidup. Jakarta: Pusat Ekologi Papua.

Soejono. R.P. 1994. Prasejarah irian Jaya dalam Irian Jaya Membangun Masyarakat Majemuk (Koentjaraningrat (ed.). Jakarta: Djambatan.

Tekege, Felix. 2009. Upaya Memurnikan Nilai - Nilai Budaya Suku Bangsa Mee dalam Kehidupan Sosial Ekonomi. Skripsi Universitas Cenderawasih. 